\title{
Selfgetuienis en interpretasie
}

\author{
PC Potgieter
}

Abstract

\section{Self-evidence and interpretation}

Hermeneutics has become a major issue in current theological thought. It is quite apparent that the interpretation of Holy Scripture is one of the most often discussed subjects amongst theologians. As to the authority of the Bible, its self-evidence is a particularly noticeable factor. This in turn has a direct bearing on the explicatio and applicatio of Scripture in preaching, and consequently on the very life of the church. It is argued that, even though the human factor should not be minimized, God Himself is subject of his Word in those various statures in which it addresses mankind.

Daar is waarskynlik geen ander faktor wat die oorsaak van soveel meningsverskil tussen teoloë is, as die uiteenlopende standpunte oor die gesag van die Skrif nie. Dit wissel van 'n volledige Biblisistiese benadering, wat die gesag van die Skrif verbind aan presiese historiese betroubaarheid tot in die noukeurigste besonderhede van alles wat in die Bybel geskryf is enersyds, tot die radikaalste vorme van Skrifkritiek, wat die geskrewe Woord as sodanig van alle Goddelike gesag stroop andersyds. In laasgenoemde geval bly dit dan mensewoorde, wat wel op ' $n$ besondere wyse deur God gebruik kan word om 'n bepaalde idee of kerugma by die leser of hoorder tuis te bring. As sodanig is dit egter nie die Woord van God nie.

Die stelling dat die Bybel God se Woord is, kan natuurlik nie empiries bewys word nie. Dit is 'n geloofs-apriori. Daarom word daar in dié verband steeds verwys na die selfgetuienis of outopistie van die Skrif. Hy dra sy geloofwaardigheid, en derhalwe sy gesag, in homself. Hierdie verband tussen geloofwaardigheid en gesag word skerp geformuleer in die Nederlandse Geloofsbelydenis: 'Ons glo ook sonder twyfel alles wat daarin vervat is . . omdat die Heilige Gees in ons hart getuig dat hulle van God is. Hulle het ook die bewys daarvan in hulleself ...' (NGB, Artikel 5).

'n Vraag wat hiermee saam aan die orde kom, is of die gesag van die Heilige Skrif deurgaans van dieselfde aard is, en of daar nie tog 
onderskei moet word op grond van die bepaalde inhoud van verskillende Skrifgedeeltes nie. Herman Bavinck het, byvoorbeeld, onderskei tussen normatiewe gesag en historiese gesag in die Bybel. Dit is immers so dat nie alles wat in die Bybel opgeteken is, in direkte sin normatiewe betekenis vir ons het nie. Sekere dele is wel histories waar, maar nie 'n algemene reël vir geloof en lewe nie. Dit beteken egter hoegenaamd nie dat die auctoritas historiae en die auctoritas normae op 'n abstrakte wyse geskei kan word nie. In sekere historiese gegewens, wat as sodanig nie vir ons normatief is nie, lê daar tog 'n gesagvolle waarskuwing of opdrag van God vir ons opgesluit. Omdat daar 'n groot verskeidenheid literêre genres in die Bybel voorkom, dra die waarheid telkens ' $n$ ander karakter, waarvolgens dit ook elke keer geïnterpreteer moet word. Dit doen egter nie in die minste enige afbreuk aan die gesag van die Skrif nie. Sowel die normatiewe as die historiese gesag is volle Goddelike gesag.

Die onderskeiding wat Heyns maak tussen skopiese en periferiese gesag - na aanleiding van die tweeledige onderskeiding met betrekking tot die boodskap van die Skrif - kan moontlik dieselfde bedoeling hê. Die gesag van die sentrale boodskap van die Bybel is skopiese gesag; dit geld alle mense en tye en omstandighede. Periferiese gesag is ontleende gesag: Dit staan in diens van die sentrale inhoud van die Skrif. Dit is egter meteens ook duidelik dat daar die moontlikheid is om hierdie onderskeiding so te interpreteer dat dit neerkom op 'n vorm van graduele inspirasie, as sou sekere dele van die Skrif meer en ander minder geinspireerd wees, en gevolglik 'n meerdere of mindere mate van gesag dra. Die terme skopies en periferies moet dus liefs nie in verband met die gesag van die Skrif gebruik word nie, alhoewel dit goedskik ten opsigte van die boodskap daarvan toepaslik kan wees.

Ten opsigte van die Skrifgesag as sodanig moet daar selfs hoegenaamd nie onderskei word nie. Die hele Skrif kom tot ons met die volle gesag van God, die Auctor primarius, en dit geld dus die geheel en al sy dele. Wie op grond van menslike insigte gaan bepaal wat meer en wat minder gesag het in die Skrif, eis vir homself 'n outonomie op wat niemand toekom nie. Vanselfsprekend moet die aard van die toepassing van hierdie gesagswoord bepaal word aan die hand van verantwoorde hermeneutiese beginsels en reëls.

Die gesag van die Heilige Skrif is in geen opsig beperk nie. Daar moet egter goed begryp word dat daar nie 'n beroep op die gesag van die Skrif gedoen mag word vir aanwending daarvan buite sy bedoeling om nie. Daarom is dit so noodsaaklik dat nie net die teoloog nie, maar ook 
die gewone Bybelleser bedag moet wees op die gevaar van 'n Biblisistiese Skrifgebruik. Waar die Bybel egter volgens sy bedoeling gelees en gebruik word, geld sy gesag die volle spektrum van die lewe. Dit geld ook vir alle mense. Die Skrif is nie net God se Woord vir gelowiges nie, maar vir almal. Ook as Goddelike imperatief is dit 'n normatiewe woord vir almal sonder enige uitsondering.

As lewende Woord van God is die Skrif ook nie tydgebonde of kultuurgebonde nie, maar tydbetrokke of tydgerig. Die Bybel is betrokke by elke tyd en gerig op die huidige situasie, net soos op die situasie van sy ontstaanstyd, maar dan vanselfsprekend in dié sin dat daar vanuit die historiese situasie en beriggewing 'n eietydse toepassing gemaak word. So bly die ewige woord hier en nou '. . . die lamp wat my die weg wys, die lig op my pad' (Ps 119: 105), ook op die pad van die eskaton.

God het sy Woord in skrifgeworde gestalte as genademiddel aan die mens gegee. Daar is egter geen sprake van 'n werktuiglike genadebemiddeling deur die Skrif nie. Wanneer dit volgens die bedoeling van die Gees gebruik word, vloei die genade en waarheid van God daardeur tot ons voordeel; wanneer dit misbruik word, haal dit die oordeel van valse getuienis oor hom wat nie ag slaan op die bedoeling van die Gees nie.

Omdat die Skrif tot ons kom in die gestalte van menslike taal en vorm, kan ons ook menslik handel daarmee. Ons kan dit gehoorsaam of veronagsaam, aanvaar of verwerp, loof of kritiseer. Maar aan die Woord self verander dit niks nie. Dit bly die middel waardeur God geloof in ons harte werk. Want die getuienis van die Gees waardeur geloof tot stand kom, is inhoudelik niks anders as die getuienis van die Skrif nie. Maar juis omdat dit die volkome werk van die oneindige God is, word die kring ook weer voltooi: Vanuit die geloof wat deur die Heilige Skrif bemiddel is, bely ons die Goddelike gesag van die Skrif. Daar is dus nie éérs 'n verifikasieweg en daarna 'n geloofsweg nie, maar omgekeerd: Wie glo, aanvaar die gesag van die Heilige Skrif (Berkouwer 1968: 11). Die geloof wat volg op die spreke van God, bely ook die gesag van die Heilige Skrif.

Wie die Bybel as boek bloot rasioneel wil benader, sal noodwendig bedroë daarvan afkom. Vertolking van die Heilige Skrif is afhanklik van sekere veronderstellings wat net langs 'n geloofsweg aanvaar kan word. Primêr is dat die lewende God Hom aan ons openbaar en dat die Skrif die 'hanteerbare' gestalte is waarin dié openbaring tot ons kom. Ook dit is nie iets wat op enige manier bewys kan word nie; dit is ' $n$ beginsel 
wat berus op geloofsaanvaarding, net soos die waarheid dat die Heilige Gees illuminerend betrokke is by die werk van die Skrifondersoeker. Bavinck (1967) noem die principia wat in geloof aanvaar moet word: God as principium essendi van die teologie; die principium cognoscendi externum of selfopenbaring van God soos neergelê in die Skrif; en die principium cognoscendi internum of illuminasie van die mens deur die Gees van God.

Dit is meteens duidelik dat daar noodwendig 'n duidelike verband moet wees tussen die aard van gesag wat iemand aan die Skrif toeken, en die vertolking wat hy aan die inhoud gee. Dit is natuurlik net so waar dat die feit van verskillende vertolkingsmoontlikhede ook skerp kritiese vrae oor die gesag van die Skrif as sodanig ontlok.

Wie die outopistie van die Skrif aanvaar, het daarmee 'n geloofskeuse gemaak: Die Skrif het gesag in homself, en dié gesag staan vas, onafhanklik van die mens se ontvangs daarvan. Die Heilige Skrif ontleen sy gesag onder geen omstandighede aan ons vertolking daarvan nie (Berkouwer 1966: 180).

Uiteraard ontstaan daar probleme wanneer elke verklaarder sy vertolking aansien as die ware bedoeling van die Woord, sodat hy hom daarmee ook meteens kan beroep op die Skrifgesag self. Wanneer daar op hierdie wyse ten opsigte van botsende standpunte 'n beroep op die Goddelike gesag gedoen word, kan dit 'n saak van die grootste verleentheid vir die kerk en die welmenende gelowige word. Dit moet derhalwe duidelik wees dat daar net in die geval van 'n werklik korrekte interpretasie van die Skrif, sprake kan wees van ' $n$ gesaghebbende uitspraak. Die vraag na 'n betroubare hermeneutiese sleutel vir die ontsluiting van die Skrif in sy ware bedoeling is van deurslaggewende belang vir die kerk en teologie.

Die diepste oorsaak van verskillende Skrifvertolkings is die verduistering van die mens se verstand as gevolg van die sondeval. Die probleem lê dus beslis nie by die Heilige Skrif self nie. As Woord van God is dit volkome duidelik, maar soos die mens as gevolg van die sondeval met die goeie skepping van God moet worstel om ' $\mathrm{n}$ bestaan, moet hy ook met die goeie openbaring van God worstel om ' $n$ verstaan. Vanweë sy sondige natuur, leef daar in die mens se hart allerlei weerstande teen ' $n$ suiwer vertolking van die Skrif. 'n Suiwer vertolking van die Skrif is meermale 'n teregwysing, 'n korreksie, op ons natuurlike neiging. Daarom die mens se verset daarteen.

Wanneer iemand die Bybel oopmaak om daaruit te lees of dit te bestudeer, doen hy dit noodwendig met bepaalde vooronderstellinge. 
Dit kan ook baie maklik gebeur dat die leser, bewus of selfs onbewus, eerder na bevestiging vir sy eie standpunt gaan soek as na die openbaring van die wil van God. So kan die Bybelleser se houding, sy lewens- en wêreldbeskouing, hom iets anders laat verstaan as wat die ware bedoeling van die betrokke Skrifgedeelte is.

Korrekte Skrifvertolking het primêr met die eer van God te doen. Die Bybel is immers sy openbaring aan ons en Hy word geëer wanneer dié openbaring op die regte wyse gehanteer word. Die ware bedoeling van die Skrif mag nie deur die mens se natuurlike neiging tot die kwaad of deur die gevolge van die sonde verduister word nie. Dat die Woord die lamp is wat ons die weg wys, en die lig op ons pad is, is nie net indikatief nie, maar ook imperatief (Ps 119: 105).

Dit spreek vanself dat die korrekte of verkeerde verstaan van die Skrif geweldige implikasies het vir die leer en die lewe van die leser. In die geval van ' $n$ bedienaar van die Woord, is die implikasies selfs nog veel groter, omdat letterlik honderde mense week na week deur sy Skrifverklaring gelei en selfs gekondisioneer word. Daarom lê die Skrif self ook soveel nadruk op die noodsaaklike waarheidskarakter van die prediking. Maar ook vir die pastorale gesprek en vir die apologetiese en polemiese diskussie is korrekte Skrifverstaan onontbeerlik. Berkouwer wys tereg op die gevaar dat die Woordbedienaar die Skrif kan vertolk op 'n manier wat met die bedoeling van die Heilige Gees so te sê niks te doen het nie. Die implikasie daarvan is doodgewoon dat God woorde in die mond gelê word wat Hy nooit gespreek het nie!

Dit is dus 'n onontkombare en selfs blywende opdrag vir die teologie om ernstig te soek na reëls wat by die bestudering van die Bybel toegepas kan word ter wille van korrekte Skrifverstaan. Hierdeur het die teologiese dissipline van die Hermeneutiek beslag gekry: Daar moes sekere sleutels aangedui word ter wille van die korrekte ontsluiting van die Bybel.

Die funksionering van die Hermeneutiek is egter nie sonder probleme nie. Vir die teologie as sodanig, en by name vir die beoefening van die Dogmatiek, het daar immers sekere gevare duidelik geword. Polman (1969: 10) wys uitvoerig op 'n uiters gevaarlike tendens wanneer die Hermeneutiek sy grense oorskry. Die negentiende eeu is gekenmerk deur'n afwysing van die Dogmatiek as legitieme vorm van teologisering. Die geweldige invloed van Karl Barth het hierdie tendens vir enkele dekades enigsins gestuit, maar in die huidige teologiese klimaat staan die Dogmatiek weer eens 'in de ban der hermeneutiek'. Die sistematisering van die Skrifwaarhede soos dit in die Dogmatiek 
gedoen word, word voorgestel as sou dit mank gaan aan soveel probleme dat dit inderdaad nie net onmoontlik is nie, maar selfs ongeoorloof, onsaaklik en ondoelmatig.

Hierdie tendens is egter nie die grootste gevaar rondom dié teologiese dissipline nie. Hermeneutiek kan ook sy grense in ' $n$ totaal ander sin oorskry en in 'n sekere sin te belangrik word. Die gevaar dat beroepsteoloë die verstaan van die Skrif as hulle eksklusiewe voorreg gaan opeis, sodat dat daar geen ruimte meer bly vir 'n gewone, eenvoudige verstaan van die Bybel nie, is nie denkbeeldig nie. Die vrees is ook nie ongegrond dat die vermenigvuldiging van teologiese probleme rondom die regte vertolking van die Skrif tot geweldige frustrasie by die gewone Bybelleser kan lei nie. Wanneer die gedagte op die gemeente oorgedra word dat die Bybel inderdaad nie die duidelikkenbare Woord van God is nie, skep dit vir die lidmaat 'n geweldige gesagskrisis rondom die belydenis van die Sola Scriptura. Dit mag nooit, maar nooit, gebeur dat die gewone Bybelleser tot die gevolgtrekking kom dat God se eintlike Woord baie ver weg, daar êrens anderkant die koninkryk van die teoloë is nie. Want wat is dan nog die sin van Bybelgebruik in die binnekamer en by huisgodsdiens?

In die reformatoriese tradisie bely ons die onfeilbaarheid van die heilige Skrif en daarmee saam sy volkome betroubaarheid (NGB, 7). En tog is dit so dat ons dikwels voor Skrifgedeeltes wat, ten minste oënskynlik, met mekaar in teenspraak is, te staan kom. So is daar onder andere direkte aanhalings van die woorde van Jesus, wat in die weergawes van die evangelies van mekaar verskil. In dié verband het Kuyper reeds tereg daarop gewys dat daar by die verklaring van die Heilige Skrif gevra moet word na die bedoeling van die Heilige Gees. Binne die ruimte wat geskep word deur die organiese inspirasieleer, is daar ' $n$ voor-die-hand-liggende verklaring vir hierdie sogenaamde diskrepansies. Wat die Heilige Gees aan ons wou oordra as Woord van God, het Hy nie alléén gedoen nie: Hy het mense gebruik as Bybelskrywers om Sy boodskap aan die kerk oor te dra en vir die kerk te bewaar. En omdat Hy hulle gebruik het net soos hulle was, elkeen met sy eie stel herinneringe en bronne, spreek dit vanself dat hulle geskrifte nie letterlik met mekaar sou ooreenkom nie. Die bedoeling van die Heilige Gees was beslis nie om vir ons 'n histories korrekte, letterlike weergawe van die woorde van Jesus te gee nie, maar om ' $n$ bepaalde Goddelike waarheid by ons tuis te bring. Op dieselfde wyse moet ons met die bedoeling van die Gees rekening hou in ons verklaring van elke deel van die Bybel in Ou en Nuwe Testament. 
Binne die ruimte van die organiese inspirasieleer kan en moet ons ook rekening hou met die kennishorison of verwysingsraamwerk van die Bybelskrywers. Al kom hulle woord tot ons uit 'n baie ongekompliseerde samelewing, beteken dit nie dat die Bybel daarom minder betroubaar is nie. Die Heilige Skrif is immers so geskryf dat sy inhoud nie gebind is aan ' $n$ bepaalde tyd nie. Die Woord geld nie minder vir die mens van die 20ste eeu met al sy tegnologiese vaardighede as wat dit vir die eerste lesers gegeld het nie. Daarom moet ons ook nie praat van die tydsgebondenheid van die Skrif of van sy uitsprake nie, maar eerder van die tydbetrokkenheid daarvan. Met hierdie onderskeiding word daar nie altyd in die teologie genoegsaam rekening gehou nie. Die sin van Skrifverklaring is immers daarin geleë om vas te stel wat dié Woord presies vir die mens van destyds wou sê, en hoe dieselfde waarheid op ons eie tyd toegepas kan en moet word. Wanneer dit so hanteer word, kom die gesag van die Skrif as sodanig vanselfsprekend nie in gedrang nie. Graafland (1973: 43v) wys tereg daarop dat mense alte maklik praat van die tydgebondenheid van die Skrif omdat hulleself tydgebonde mense is.

As daar een ding is wat nie sterk genoeg beklemtoon kan word nie, is dit dat ons deur ons behoefte aan vertolking van die Heilige Skrif, nooit die Bybel as gegewenheid op die agtergrond mag dring nie. Daar moet inderdaad vryheid van eksegese wees en daar moet hermeneutiese reëls toegepas word, maar daar moet steeds 'een geduldige concentratie op de Schrift zelf' wees (Berkouwer 1966: 199). Die Heilige Skrif is volledig betroubaar in wat dit bedoel om te sê. Die groot verantwoordelikheid wat rus op die skouers van die teoloog is om hom eksegeties deeglik te kan verantwoord ten opsigte van die ware bedoeling van die Skrif.

In dié verband is dit belangrik om daarop te let dat die bepaalde woorde wat in die Heilige Skrif gebruik word, inderdaad van groot belang is. Dit is nie maar net die gedagtes of waarhede agter die woorde wat die geïnspireerde woord van God is nie. Die pasa grafé van 2 Timoteus 3: 16 laat ons duidelik verstaan dat ons die waarhede in die Bybel nie kan losmaak van die bepaalde vorm waarin hulle gestel word nie. Deur die sorg van die Heilige Gees het die skrywers nie woorde gebruik wat 'n ander betekenis sou gee aan die saak wat God in die Bybel vir ons wou bewaar nie. In hierdie betekenis is die bepaalde woorde wat die eerste skrywers gebruik het, geïnspireerde woorde: Nie as losstaande woorde nie, maar as Skrifwoorde binne 'n bepaalde konteks. 
Die deurslaggewende vraag is vanselfsprekend hoe daar te werk gegaan moet word om die Skrif korrek te vertolk. Dit is noodsaaklik dat die sleutel daarvoor in die Skrif self gevind word; die gebruik van enige buite-Bybelse hermeneutiese sleutel sou meteens die prysgawe van die prioriteit en Goddelike gesag van die Heilige Skrif impliseer.

Dit is egter so dat talle hermeneutiese sleutels wat juis nie aan hierdie primêre vereiste voldoen nie, deur die loop van die jare vir dié doel aangedien is. Die spiritualistiese sleutel van 'n pneumatiese of allegoriese eksegese, en die rol wat dit in die geskiedenis van die kerk en in die teologie gespeel het, is bekend genoeg. Daarbenewens is ' $n$ verskeidenheid van sleutels wat eintlik ' $n$ bepaalde wysgerige onderbou het, aan die hand gedoen.

Die invloed van Rudolf Bultmann met sy eksistensiale interpretasiemetode moet ook in die huidige teologiese denke nie onderskat word nie. Dit gaan vir hom veral oor die moderne mens se verstaan van die boodskap van die Nuwe Testament. Elke sweem van 'n verouderde Bybelse wêreldbeeld, wat vir die hedendaagse mens ' $n$ aanstoot is, moet verwyder word, sodat hy tot ' $n$ nuwe verstaan van homself en die wêreld kan kom. Wat ons moet insien volgens Bultmann, is dat die 'onaanvaarbare' elemente in die Skrif maar blote mitologiese inkleding is van die eintlike kerugma van die Bybel. Daarom is die skynbaar objektiewe uitsprake in die Bybel oor God nie bedoel as objektiewe mededelinge nie. Dit is net ' $n$ objektiverende manier van praat oor eksistensiële gebeurtenisse, en dus bloot subjektiewe belydenisse oor wat God aan die mens gedoen het. Die Nuwe Testament moet geontmitologiseer word deur deur te dring tot die diepste bedoeling daarvan. Dit kan net gebeur wanneer die leser (eksegeet) die Selbstverständnis van die skrywer ontdek. Die moontlikheid daartoe lê in die gemeenskaplike bestaanstrukture van alle mense - die sogenaamde eksistensiale - daarom: eksistensiale interpretasie.

Dit is merkwaardig dat Hans Küng hom in die verdediging van sy eksegetiese metode teenoor die Rooms-Katolieke Kerk beroep op die noodsaaklikheid van 'n konsekwente Skrifgeoriënteerde teologie (Küng \& Moltmann 1980: 87). Wanneer hy hom dan vir dié doel bedien van die histories-kritiese metode van Skrifondersoek, verloën hy sy eie beginsel deur die Skrifinhoud as sodanig aan die kritiek van die menslike rede te onderwerp. Dieselfde gevaar staan ook lewensgroot op die agtergrond by Schillebeeckx met sy hermeneutiese beginsel dat die ortopraksie die verifikasie-beginsel van die ortodoksie is ('aan hun vruchten zult ge ze kennen' - Congar 1968: 106): Die toets wat aangelê 
word, is dié van 'n verklaringsbeginsel wat van buite die Skrif self geneem is.

Met hierdie soort vertrekpunt kom die eksegeet nie verder as uitleg op grond van eie insig nie, sodat dit telkens weer uitloop op 'n miskenning van die Skrifgesag. Daarom is die nadruklike waarskuwing van die apostel ter sake: 'Dít veral moet julle weet: Geen profesie in die Skrif kan op grond van eie insig reg uitgelê (epiluseōs) word nie ...' (2 Pet 1: 20). Ons uitgangspunt moet derhalwe altyd die teks self bly. Daarom ook die merkwaardige stelreël van die Reformasie: sacra Scriptura sui ipsius interpres - die heilige Skrif is sy eie verklaarder.

Vanselfsprekend gaan dit hier nie om 'n dooie letter wat verklaar moet word nie. Dit gaan om Skrifgetuienis wat deur die geloof en onder leiding van die Heilige Gees met Skrifgetuienis vergelyk word. So word ons deur die Heilige Gees gelei op die weg van 'n korrekte vertolking van die Skrif, terwyl die sleutel steeds die Bybelse gegraptai (daar staan geskrywe) bly. Die eenvoudige implikasie hiervan is dat ons die Skrifwoorde altyd in hulle volle konteks sal lees: Kerugmaties, maar ook literêr en kultuur-histories. Dit is immers ook die finale vrywaring teen Biblisisme.

Wanneer die belangrike beginsel van die Skrif as sy eie verklaarder aanvaar word, impliseer dit nie dat die verklaringsfunksie van die teologie as wetenskap daarmee uitgeskakel is nie. Wat wel volg, is dat alle verklaringsbeginsels waarmee die teologie werk, Skriftuurlik gefundeer moet wees. Hierdie siening kan ook goed verantwoord word vanuit die vertrekpunt dat die objek van die teologie die Heilige Skrif is.

Die teologie gaan ook as vakwetenskap juis van Skrifkennis gebruik maak om die Skrif self reg te vertolk.

Dit spreek vanself dat daar sekere hulpwetenskappe is wat ' $n$ bydrae sal lewer sodat die teologie sy funksie soveel beter kan vervul: Die bestudering van die grondtale van die Bybel, sekere dissiplines in die humaniora, die wysbegeerte en moontlik heelwat meer. Maar selfs langs dié weg word die wetenskap op sigself nooit mede-verklaarder van die Skrif nie, soos GC Berkouwer volkome tereg aantoon. Kennisontsluiting vanuit die Bybel moet altyd langs die weg van die sui ipsius interpres geskied.

Sedert die verskyning van Berkouwer se belangwekkende dogmatiese studies oor die Heilige Skrif, het die diskussie oor Skrifinspirasie, Skrifgesag en Skrifverstaan in gereformeerde kring geweldig toegeneem. Dit blyk onder andere daaruit dat Skrifbeskouing die onderwerp 
van bespreking geword het by talle teologiese kongresse, maar ook by konferensies van predikante; dat dit vir ondersoek deur sinodes aan studiekommissies opgedra is; dat talle artikels daaroor in wetenskaplikteologiese tydskrifte en in die populêre kerklike pers verskyn het; dit is tewens meermale die onderwerp van lewendige diskussie in die korrespondensiekolomme van kerklike blaaie.

Een van die mees kontroversiële gebeurtenisse van dié tyd was die publikasie van 'n verslag wat voor die Delftse sinode van die Gereformeerde Kerken Nederland gedien het. Aan dié verslag, wat in 1980 onder die titel God met ons gepubliseer is, het onder andere meegewerk proff Baarda, Firet, De Moor, Van Peursen en Veenhof. Soos die subtitel aandui, is die primêre vraag wat aan die orde gekom het dié na die aard van die Skrifgesag. Vanselfsprekend is daar dan ook indringend aandag gegee aan die sleutel vir korrekte Skrifvertolking. Reeds uit die inleiding blyk dat die deputaatskap wat vir die verslag verantwoordelik was, tot die gevolgtrekking gekom het dat die Bybel net reg geïnterpreteer kan word indien daar uitgegaan word van die sogenaamde 'relationeel waarheidsbegrip'.

Dit is uit die staanspoor duidelik dat daar in die rapport God met ons, geopereer word met 'n bepaalde wysgerige waarheidsbeskouing. Die opstellers wil twee tendense van die hand wys. Enersyds is daar die gevaar van 'n objektiewe waarheidsbegrip: 'n Mededeling is net waar as dit presies met die werklikheid van die gebeure wat meegedeel word, ooreenstem. Hier gaan dit dus om 'n presiese, histories-korrekte weergawe van wat gebeur het. Merkwaardig genoeg funksioneer hierdie waarheidsbeskouing by twee wyd uiteenlopende rigtings: By die fundamentalisme, maar ook by die voorstanders van 'n positiwistiese Skrifkritiek. Aan die anderkant staan 'n subjektiewe waarheidsbegrip, waar die waarheid self afhanklik gestel word van die kennende subjek: lets is net waar as die mens kan insien dat dit waar is. Op 'n rasionalistiese wyse word die waarheid in dié geval dus bepaal deur wetenskaplike of filosofiese insigte.

Hierteenoor stel die rapport dan dat die waarheid nòg objektief nòg subjektief is, maar relasioneel. Sowel die objektiewe as die subjektiewe kante moet verreken word om die waarheid te ken. Die waarheid kan nie anders geken word nie as op 'n eksistensiële wyse, met ander woorde, in die mens se persoonlike betrokkenheid by dít waarvan hy kennis neem.

In die lig van hierdie siening word daar dan gevra na ons kennis van die Bybel se waarheid. Die voor-die-hand-liggende antwoord is dat ons 
dié waarheid net in 'n gelowige omgang met die Skrif kan ken. In die Skrif gaan dit inderdaad om geloofswaarhede waarvan ons net in 'n persoonlike verhouding tot Christus ware kennis kan hê. Dit beteken egter nie dat die waarheid van die Skrif afhanklik is van die mens se geloof nie. Die waarheid word nie deur die geloof geskep nie, maar slegs ontvang, stel Berkouwer tereg. Die Skrif word nie eers waar as die mens dit hoor en gelowig ken nie, maar is waar omdat dit die Woord van God is. Die hantering van 'n relasionele waarheidsbegrip moet noodwendig uitloop op subjektiwisme en relatiwisme. Dit is dan ook nie vreemd dat die rapport self in soveel woorde stel dat die waarheid wat ons in die Skrif vind, persoonlik bepaald is nie. Die implikasie daarvan is duidelik genoeg: Wat daar geskrywe staan, kan vir een leser of hoorder ' $n$ ander waarheid inhou as vir die volgende leser of hoorder! Daarmee het die normatiwiteit van die Skrif tot so 'n mate in gedrang gekom, dat die vraag na Skrifgesag bykans irrelevant geword het. Die dilemma rondom leertug waarin die Gereformeerde Kerken Nederland (GKN) hom teen die einde van die sewentigerjare bevind het (Kuitert, Wiersinga) moet sonder die minste twyfel met hierdie siening in verband gebring word.

Dit is natuurlik so dat die waarheid relasionele aspekte het, maar as sodanig is dit nie relasioneel nie. Die waarheid van God is geopenbaar in die dinamiek van God se Woord. Wanneer die gegraptai - dit wat geskryf is - as gegewenheid onderwaardeer word, kom die gesag van die Heilige Skrif altyd ernstig in gedrang.

In die rapport val die klem veels te swaar op die menslike faktor in die inspirasie. Dit geld nie net ten opsigte van die Bybelskrywers nie, maar selfs ook van die lesers. Met goeie grond is die kritiese opmerking gemaak dat die rapport uiteindelik ook nie meer die noodsaaklike onderskeiding tussen inspirasie en illuminasie duidelik handhaaf nie.

Wanneer die rapport in sy geheel gelees word, wek dit buitendien ook die indruk dat minstens ' $n$ bepaalde vorm van graduele inspirasie goed aanvaarbaar is: Die Skrif is nie in al sy dele op dieselfde wyse en in dieselfde mate geïspireer nie.

Selfs al ontken die opstellers van die rapport dit uitdruklik, plaas hierdie siening die toegang van die gewone leser tot die Bybel as geskrewe Woord van God ernstig in die weegskaal, soos WD Jonker in sy kritiek volkome tereg aantoon. Wetenskaplike teologie word so ongeveer 'n sine qua non vir 'n korrekte verstaan van die Skrif, want sonder kennis van die histories-kritiese metode kan die Bybel eintlik nie reg gebruik word nie. 'Die gebruik van die Bybel as suprema iudex 
controversiarum in direkte sin, word onmoontlik as gevolg van die relasionele waarheidsbegrip wat op ons kontekstuele omgang met die Bybel berus' (Jonker 1982).

Dit alles hou natuurlik geweldige implikasies vir die prediking in. Sonder explicatio kan daar geen applicatio wees nie. Maar sonder goeie hermeneutiek val albei deur die mat.

Dit is merkwaardig dat die Bybel sonder enige terughoudendheid van die gepredikte woord praat as die Woord van God. Paulus stel dit sonder meer aan die Tessalonisense dat hy God daarvoor dank 'dat julle die boodskap van God wat julle van ons gehoor het, ontvang en aangeneem het in die oortuiging dat dit nie mensewoorde is nie, maar die woord van God. En dit is ook inderdaad die woord van God ...' (1 Tess 2: 13). Die prediking is alēthōs logon theou, werklik, sonder enige twyfel, die Woord van God. In sy kommentaar wys Calvyn op die dubbele implikasie hiervan. Vir die leraar is dit 'n geweldige vermaning om niks anders as die suiwer Woord van God te verkondig nie. En wat die hoorder betref: Baie mense besef nie dat hulle in die woord wat deur die verkondiging tot hulle kom, met God self te doen het nie; hulle moet goed weet dat die prediking nie maar die ydele, persoonlike mening van die leraar is nie. Ewe aangrypend is die apostel se woord aan die Korintiërs: 'Ons tree dus op as gesante van Christus, en dit is God wat deur ons 'n beroep op julle doen; ( 2 Kor 5: 18-20); en Christus se eie woord aan die wat Hy uitgestuur het: 'Wie na julle luister, luister na My' (Luk 10: 16).

Wat Christus beloof het aan sy Kerk in verband met die leiding van die Heilige Gees (Joh 14: 26; 16: 13-15), het klaarblyklik pertinent betrekking op die prediking van die Woord. Die primêre genademiddel wat deur die Gees van God gebruik word om die verlossing in Christus by die mens tuis te bring en in hom tot ' $n$ realiteit te maak, is die Woord. Die vraag is egter of dit net die Woord in sy skrifgeworde gestalte is, en of dit ook gesê kan word van die Woord in sy verkondigingsgestalte. Dat laasgenoemde inderdaad ook die geval is, blyk duidelik uit verskillende uitsprake van die Skrif self: 'Die geloof kom dus deur die prediking wat ' $n$ mens hoor, en die prediking wat ons hoor, is die verkondiging van Christus' (Rom 10: 17); en wanneer die apostel verwys na die prediking in die gemeente, sê hy sonder meer dat die 'uitwerking daarvan' op die wat glo, die bewys is dat dit inderdaad 'nie mensewoorde is nie, maar die woord van God' (1 Tess 1: 13).

Daar kan dus geen sprake wees van enige spanning of dualisme tussen die gesproke woord en die geskrewe Woord van God nie. 
Merkwaardig is dat hierdie soort spanning nie net gevind word waar daar' $n$ onderwaardering van die gepredikte woord is nie, maar juis ook by die oorskatting daarvan. ' $n$ Tipiese voorbeeld van laasgenoemde is Ebeling, vir wie die verkondigde woord die eintlike Woord is, die viva vox evangelica.

Die Heilige Gees werk deur die Woord van God in al sy verskillende gestaltes: As Skrifgeworde Woord maar ook as Woord in sy verkondigingsgestalte is dit'n lewewekkende Woord omdat dit tot geloof bring.

In dié verband is ' $n$ opmerking van AA van Ruler (1986: 113-128) besonder interessant: Die outopistie van die Heilige Skrif het 'n teenpool in die kerk, naamlik die testimonium Spiritus Sancti internum, sodat die uitwendige gesag van die Skrif inwendig bemiddel word deur die Heilige Gees. Die Skrifgesag kom juis by die hoorder tuis wanneer die Heilige Gees deur bemiddeling van die ampte in die kerk werk. Daarom mag die kerk nie net die Woord wat hy biddend ontvang met gesag verklaar nie; hy moet dit selfs doen; met ootmoed, maar ook met geloofsmoed.

Dat die Reformasie die innige verband tussen die gekrewe Woord en die verkondigde Woord sonder meer gehandhaaf het, is baie duidelik uit die eerste hoofstuk van die Tweede Helvetiese Konfessie (Confessio Helvetica Posterior 1566): Kort op die stelling dat die Skrif die Woord van God is, volg die onomwonde belydenis dat die 'prediking van God se Woord die Woord van God is.'

Inderdaad. Want soos God die Auctor primarius van die Skrif is, is $\mathrm{Hy}$ ook die Praedicator primarius van die verkondigde Woord. God is subjek van sy Woord in al die gestaltes daarvan. In die prediking bring God sy Woord deur die diens van mense en met gebruik van mensewoorde. Daarom mag die prediking ten diepste net een ding ten doel hê: Om die Woord van God aan die woord te laat. Dit is allermins die plek vir die persoonlike mening en gefabriseerde spitsvondighede van die prediker. Want agter die prediker staan die sprekende God wie se eie Woord in die erediens werksaam is deur die Heilige Gees. Daarom aarsel Calvyn ook nie om in sy kommentaar op 1 Tessalonisense 2: 13 te sê dat die woord van die prediking niks anders is nie as (nihil aliud quam) die Woord van God. Daarom is die prediker ook Verbi divini minister.

En tog moet daar hieroor geen misverstand wees nie: As ons sê dat die Woord in sy verkondigingsgestalte inderdaad die Woord van God is, is daarmee nog nie gesê dat alle prediking Woordverkondiging is nie. Daar is ' $n$ duidelike voorwaarde hieraan verbonde. As die prediker werklik die Here se Woord met gesag wil preek, mag die inhoud van sy 
prediking niks anders sê as wat die Heilige Skrif sê nie, al is dit dan in sy eie woorde. En daarvoor is hy ten volle aangewys op die beloofde leiding van die Heilige Gees.

\section{Literatuurverwysings}

BAVINCK, H 1967. Gereformeerde Dogmatiek, Vol I. Kampen: Kok. BERKOUWER, GC 1966. De Heilige Schrift, Vol I. Kampen: Kok. BERKOUWER, GC 1967. De Heilige Schrift, Vol Il. Kampen: Kok. BERKOUWER, GC (red) 1968. De Bijbel in het geding. Nijkerk: Callenbach. BERKOUWER, GC 1969. Verontrusting en verantwoordelijkheid. Kampen: Kok. BERKOUWER, GC 1974. Een halve eeuw van theologie: Kampen: Kok.

CONGAR, Y 1968. Theologen antwoorden. sl.

EBELING, G 1960. Wort und Glaube, I. Tübingen: Mohr.

EBELING, G 1969. Wort und Glaube, II. Tübingen: Mohr.

GRAAFLAND, C 1973. Waarom nog gereformeerd? Kampen: Kok.

HEYNS, JA 1978. Dogmatiek. Pretoria: NG Kerk-Boekhandel.

JONKER, H 1980. Gereformeerde prediking in onze tijd. Apeldoorn: De Zwijgerstichting.

JONKER, WD 1982. How free is theology? Theological Forum 9, 3/4 46-50.

KÜNG, H \& MOLTMANN, J 1980. Conflicting ways of interpreting the Bible. Edinburgh: Clark. (Concilium 138, 8/1980.)

KUYPER, A 1894. Encyclopaedie der Heilige Godgeleerdheid, Il. Amsterdam: Dusseau.

OTT, H 1981. Die Artwort des Glaubens: Systematische Theologie in 50 Artikeln, 3. Überarbeitete und erweiterte Auflage. Stuttgart: Kreuz.

POLMAN, ADR 1969. Gereformeerde katolieke dogmatiek, I. Kampen: Kok.

POTGIETER, PC 1985. Hier is die Woord. Wellington: Bybelkor.

RIDDERBOS, H 1965. De speelruimte van de Geest. Gereformeerd Weekblad.

VAN RULER, AA 1968. Schriftgezag en kerk, in GC Berkouwer \& Van der Woude, AS (reds), De Bijbel in het geding, 113-128. Nijkerk: Callenbach. 